the British Association, he has visited Canada, Australia and South Africa, and is otherwise widely travelled. Sir Albert's election to the presidency of the British Association will be welcomed by all men of science, especially botanists and geologists.

\section{Cambridge Meeting of the British Association}

THE meeting of the British Association which has just closed will long be remembered by all who attended it. At the first meeting of the General Committee, it was agreed to form a Division for Social and International Relations of Science (see p. 380), which may well prove a vital step in the history of the Association. Lord Rayleigh's address was received with much enthusiasm, and a specially warm welcome was given to Sir J. J. Thomson, who moved a vote of thanks to the president for his address, and also to Dr. G. D. Birkhoff, past president of the American Association for the Advancement of Science, who, as spokesman of the delegation from his Association, expressed his desire to see active co-operation between the British and American Associations in the cause of international friendship. The customary announcement at the close of the inaugural meeting, made by Dr. O. J. R. Howarth in the absence of the general treasurer, Lord Stamp, of the number of tickets issued for the meeting, showed that the attendance, 2,795, while not a record, was highly satisfactory. The services of broadcasting were utilized to bring the Association's activities before a wider audience in Great Britain and also in the United States. Prof. Allan Ferguson broadcast an account of the opening meeting through the B.B.C., while on August 19, Lord Rayleigh and Sir Richard Gregory were 'interviewed' before the microphone by Mr. Watson Davis, director of Science Service, and the 'interview' broadcast in America.

THE setting at Cambridge for the meeting was of course ideal, and the University and individual colleges showed their traditional hospitality. In addition to the discussions and papers before the several sections, members had an opportunity of inspecting an exhibition of old and historic scientific instruments, which appropriately included apparatus used by Sir J. J. Thomson and by Lord Rutherford, of seeing demonstrations and exhibits of gold films produced by Prof. C. S. Gibson and his collaborators, and other more 'sectional' exhibitions. The officers of the Association who have been elected for 1939 are as follows : President, Sir Albert Seward; General Treasurer, Prof. P. G. H. Boswell ; General Secretaries, Prof. F. T. Brooks and Prof. Allan Ferguson; New Members of Council, R. W. Allan, Prof. F. E. Fritsch, Sir Richard Gregory, Prof. C. Spearman and Dr. C. R. Fay. Future places of meeting of the Association will be Dundee (1939), Newcastle-on-Tyne (1940), Belfast (1941) and Birmingham (1942).

\section{Impressions of Cambridge}

A CORRESPONDENT writes: "Cambridge is the best of all places for the British Association to meet. There was an air of activity and exhilaration throughout the week, and the organization was carried out with extraordinary smoothness. There were almost too many receptions, dinners and garden parties; perhaps one could wish for a little more time for those discussions behind the scenes which are the most valuable feature of these gatherings. The great novelty of the meeting was, of course, the formation of the Division for the Social and International Relations of Science. It was astonishing and encouraging to find the project so enthusiastically received by the widest variety of scientific workers. It has lit up many people's imaginations, and given them a chance to devote themselves intelligently to something which offers a hint of usefulness in an increasingly lunatic world. Perhaps the shadow of the world outside has never hung so menacingly over a scientific meeting; many there felt that all they cared for intellectually might have vanished before long. It was noticeable that the most eager supporters of the new Division were often those whose own research happened to be particularly 'pure'. Those who complained in private that the cobbler ought to stick to his last usually turned out to be engaged on semi-applied research. It is, for example, interesting that the more abstract kind of physicists tend to be far more socially interested than people busy with traditional chemistry."

"DARWIN's was easily the most exciting presidential address, and a model which other sections might usefully study. It had the great advantage that the intelligent layman could listen to it and not waste his time; and yet it also contained ideas enough to set professional scientists and philosophers arguing for weeks. Childe's and Southwell's were also nice pieces of work, and Griffith Taylor's highly entertaining. For pure science, Blackett's Saturday morning talk on cosmic rays was unsurpassed. The trouble is, one wants to go to so many lectures that are taking place simultaneously. But still, an energetic person could have heard something from Wells, Bohr, Darwin, Keynes, Blackett, Shapley and Huxley-which is not such a bad bag for a week's holiday."

\section{Art at the British Association}

A COLLECTION of photographs taken by members of the scientific delegation from Great Britain to the Indian Science Congress Association's jubilee meeting in January of this year was exhibited in the reception room of the British Association at Cambridge. Some of the photographs were of scientific personalities, others of Indian scenes and inhabitants, whereas several gave beautiful impressions of certain wellknown Indian buildings at night, flood-lit and illuminated. A very pleasing innovation at this year's meeting, too, was the exhibition of works of art by members of the Association, which demonstrated very clearly that genius is not confined to a single avenue of interest. Many outstanding men of science are known to be accomplished in one or other of the arts, especially music, but this exhibition must have proved a pleasant surprise to many. Well over a hundred examples were exhibited, the chief among them being oil and water colour paint. ings, though examples also of ware, metal-work and 